\title{
Usability analysis of 2D graphics software for designing technical clothing
}

\author{
Rita de Cassia Clark Teodoroski $\mathrm{i}^{\mathrm{a},}{ }^{,}$, Edilene Zilma Espíndola ${ }^{\mathrm{b}}$, Enéias Silva ${ }^{\mathrm{c}}$, Antônio Renato Pereira \\ Moro $^{\mathrm{d}}$ and Vera Lucia D. V. Pereira ${ }^{\mathrm{e}}$ \\ ${ }^{a}$ Coordenação do Curso de Fisioterapia, Faculdade Estácio de Sá de Santa Catarina. E-mail: \\ rita.teodoroski@estacio.br.SC,Brasil. \\ ${ }^{\mathrm{b}}$ Universidade Federal de Santa Catarina.E-mail: ezem9824@yahoo.com.br. SC, Brasil. \\ ${ }^{\mathrm{c} U n i v e r s i d a d e ~ F e d e r a l ~ d e ~ S a n t a ~ C a t a r i n a . E-m a i l: ~ e n e i a s @ e n e i a s . c o m . ~ S C, ~ B r a s i l . ~}$ \\ ${ }^{\mathrm{d}}$ Programa de Pós-Graduação em Engenharia de Produção. Universidade Federal de Santa Catarina. E-mail: \\ moro@deps.ufsc.br.SC,Brasil. \\ 'Programa de Pós-Graduação em Engenharia de Produção e Núcleo de Gestão de Design, Universidade Federal \\ de Santa Catarina. E-mail: vpereira@deps.ufsc.br.SC, Brasil.
}

\begin{abstract}
With the advent of technology, the computer became a working tool increasingly present in companies. Its purpose is to increase production and reduce the inherent errors in manual production. The aim of this study was to analyze the usability of 2D graphics software in creating clothing designs by a professional during his work. The movements of the mouse, keyboard and graphical tools were monitored in real time by software Camtasia $7 \AA$ installed on the user's computer. To register the use of mouse and keyboard we used auxiliary software called MouseMeter ${ }^{\circledR}$, which quantifies the number of times they pressed the right, middle and left mouse's buttons, the keyboard and also the distance traveled in meters by the cursor on the screen. Data was collected in periods of 15 minutes, 1 hour and 8 hours, consecutively. The results showed that the job is considered repetitive and high demands physical efforts, which can lead to the appearance of repetitive strain injuries. Thus, the goal of minimizing operator efforts and thereby enhance the usability of the examined tool, becomes imperative to replace the mouse by a device called tablet, which also offers an electronic pen and a drawing platform for design development.
\end{abstract}

Keywords: Technology, Applicability, Ergonomics, Repetitive Strain.

\section{Introduction}

With the advent of technology, the computer became a working tool increasingly present in companies. Its purpose is to increase production and reduce the inherent errors in manual production, but if not used properly can cause irreversible damage to workers' health.

The designer or fashion designer spends all his efforts developing technical drawings based on season trends. "The designer creates, develops from the shape, color and fashion trends of research" [1]. The models' clothes are developed, on average, six months before being released in the market. There are demands that necessitate the work of these professionals. The creation of specific software facilitates the preparation of drawings, but the consequent overuse of the mouse and keyboard can lead to several physical damage to the user, which should be considered in an ergonomic analysis.

The aim of this study was to analyze the usability of 2D graphics software, Audaces Idea Nasnuvens in creating clothing designs by a professional during his work.

\footnotetext{
* Corresponding author: Rita de Cassia Clark Teodoroski. E-mail: rita.teodoroski@estacio.br.
} 


\section{Theoretical Foundation}

\subsection{Clothing Technology}

"Fashion can be understood as a production and communication system which causes behavior and appearance changes, following the culture and seasonal trends" [2]. Fashion and design are two recent concepts in the academia, but can be joined giving rise to professionals termed as fashion designer [2].

"The fashion industry has some peculiarities, considering that the manufacturing steps of a garment are fragmented" [3]. Still, in seeking to increase production and meet the competition, many companies invest in new technologies in the clothing [4,5]. "The developed modeling on the computer screen is an innovation introduced by the computer" [6]. "Computer technology is undoubtedly a great ally in this sector too professional" [2] and goes on to say that "work at other times took a long time one of professional preparation, today is greatly facilitated by the use of software" [2]. However, as with all computerized production process, despite the risk posed by inappropriate and excessive use-able, there is no doubt that this technology facilitates the accomplishment of the task of helping to increase productivity and to improve marketing competition.

\subsection{Musculoskeletal Disorders}

Over the years, in line with technological changes, many changes occurred in the working methods with direct repercussions on the health of the worker $[7,8,9]$. The inappropriate and excessive use, especially in the region of the upper limbs, can lead to the appearance of occupational diseases [10].

Considered as multifactorials $[8,11,12,13]$ and recognized as professional diseases in the $80^{\prime}$ $[10,12,14]$, musculoskeletal disorders are characterized as "disorders neuro-musculo-tendinous origins of occupational affecting the upper limbs and neck, caused by repetitive use and forced the muscle group or movement forced posture" [14].

In these disorders, pain is considered the main symptom of gradual onset in an anatomical region, e.g., wrist, elbow and shoulder, until the entire upper limb [14]. The same authors also describe that in addition to complaints of localized pain, the worker also reports irradiation to the limbs, tingling, swelling, stiffness and limitation of movement amplitude in association with generalized symptoms such as anxie- ty, irritability, mood alteration and sleep, tension headache and fatigue.

\subsection{Ergonomic Analysis of Work (EAW)}

In the context of real work situations, the ergonomist is faced with the need to transform the actions to meet the goals of ergonomics. It uses EAW in its various stages: demand analysis, task and activity that will draw a diagnosis and, finally, the recommendations [15]. "Transform the work is the first purpose of ergonomic action" [16], and the ergonomic analysis of work "aims to apply the knowledge of ergonomics to analyze, diagnose and fix a real work situation" [17].

\section{Methodology}

The research, of qualitative and quantitative nature, has a descriptive character, such as case study and the data were obtained during the working activity of a user of that software. The movements of the mouse, keyboard and graphical tools were monitored in real time by software Camtasia $7 \AA$ (FIGURE 1) installed on the user's computer, which enabled the visualization of the entire process of creating and implementing the design. To register the use of mouse and keyboard during the work, we used auxiliary software called MouseMeter ${ }^{\circledR}$ (FIGURE 2), which quantifies the number of times they pressed the right, middle and left mouse's buttons, the keyboard and also the distance traveled in meters by the cursor on the screen. Data was collected in periods of 15 minutes, 1 hour and 8 hours consecutively.

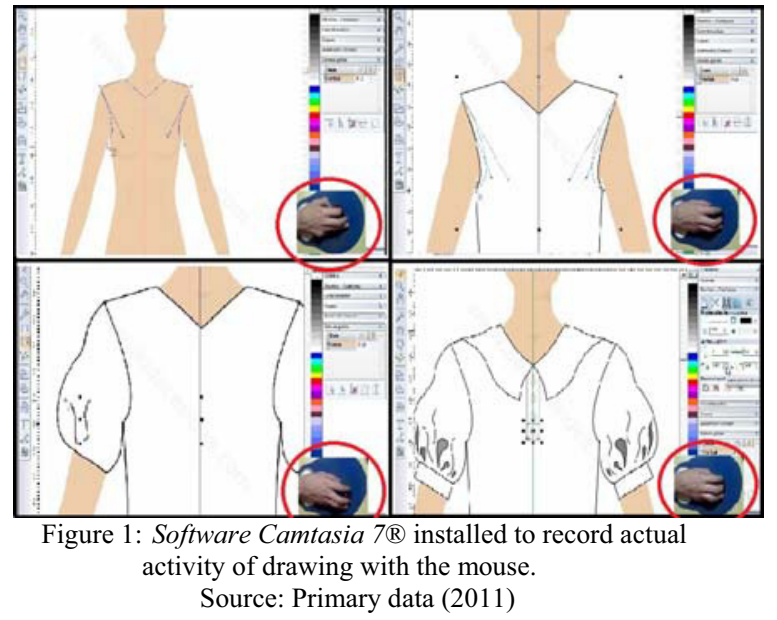




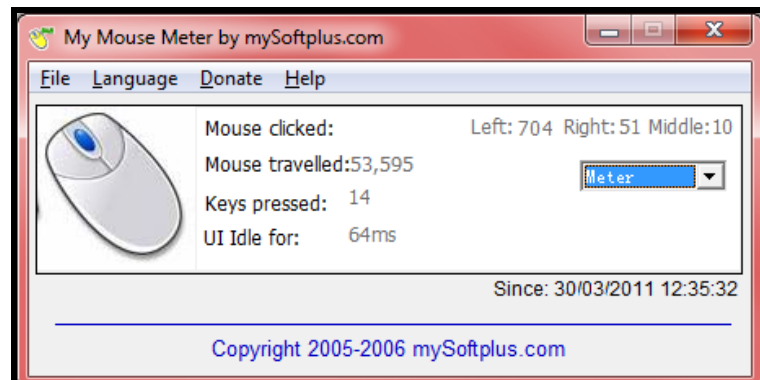

Figure 2: Register of the usability of the mouse during the workday with the program MouseMeter ${ }^{\circledR}$ Source: My Mouse Meter (2011) [18]

\section{Results and Discussion}

The results can be visualized in the Table 1 . Concerning the number of touches of the right button were $704,2,816$ and 22,528 , respectively. In periods of 15 minutes, 1 hour and 8 hours, consecutively, with the left button was performed 51, 204 and 1632 clicks and with the middle 10, 40 and 320. Regarding the handling of the keyboard, results indicate that it was used 14 times in 15 minutes, 56 in 1 hour and 448 in eight hours. The distance traveled by the cursor on the screen was 53.595, 214.380 and 1.715.040 meters within the same time.

Table 1: Results concerning the number of touches, handling of the keyboard and distance traveled by the cursor on the screen.

\begin{tabular}{|l|c|c|c|}
\hline & $15 \mathrm{~min}$ & 1 hora & $\mathbf{8}$ horas \\
\hline BOTÃO DIREITO & 704,000 & $2.816,00$ & $22.528,000$ \\
\hline BOTÃO ESQUERDO & 51,000 & 204,000 & $1.632,000$ \\
\hline BOTÃO MEIO & 10,000 & 40,000 & 320,000 \\
\hline TECLAS & 14,000 & 56,000 & 448,000 \\
\hline DISTÂNCIA Source: Primary data (2011) & 53,595 & 214,380 & $1.715,040$ \\
\hline
\end{tabular}

"The ability to draw is of great importance to the professional fashion" [19] in the same way that "the design helps to understand the process of creating, structuring and feasibility of making the play" [19]. However, "it is essential to continuous improvement of working conditions for this to be done, such that loads from the activity being performed or to be held does not exceed the limits of the worker" [7].

According to the Ministry of Health [20], "the recognition of risk factors in the work involves a set of procedures designed to determine whether or not there is a problem for the health of the worker". "For an ergonomic intervention, we should perform the identification and quantification of risk factors present in the workplace" [8]. In this study, it became clear that the repetitive stress during the workday was the predominant risk factor is therefore essential for pauses during the work activity to promote a compensation for the service performed, as described in "b "item 17.6.3 of Norm's Work No. 17 - NR17 [21].

Another way to minimize the effort is through a device that replaces the mouse, called tablet (Figure 3 ), which "is a device formed by a set of pen and a little sensitive to this tablet pen" [22]. Such a device is intended to enable the construction of the design similar to the traditional way.

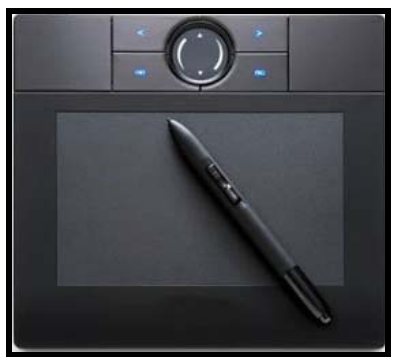

Figure 3: Tablet - device formed by the pen and clipboard to draw. Source: Tablet (2011) [22]

\section{Conclusion}

The results showed that the job in relation to the use of the mouse and keyboard is considered repetitive and high demands physical efforts, which can lead to the appearance of repetitive strain injuries.

Thus, the goal of minimizing operator efforts and thereby enhance the usability of the examined tool, becomes imperative the introduction of breaks during the workday and to replace the mouse by a device called tablet, which also offers an electronic pen and a drawing platform for design development.

\section{References}

[1] Dall'Onder, G. S. Análise projetual de metodologia para desenvolvimento de produto de moda na indústria do vestuário. 50 fl. 2007. Trabalho de Conclusão de Curso (Tecnólogo em Tecnologia do Vestuário) - União de Ensino do Sudoeste do Paraná, Dois Vizinhos, Paraná, 2007. Disponível em: $<$ http://www.modavestuario.com/gracielascopeldallonder.pdf $>$ Acesso em: 15 maio 2011

[2] Santos, Caroline Zanardo Gomes dos; SANTOS, Joyce Ribeiro dos. Design de moda: o corpo, a roupa e o espaço que os habita. Saber Acadêmico. n. 9, p. 204-213, jun./2010. ISSN 1980-5950. Disponível em:

$<\underline{\text { http://www.uniesp.edu.br/revista/revista9/pdf/artigos/17.pdf }>}$. Acesso em: 24 set. 2011. 
[3] Rech, Sandra Regina. O gestor de design de moda: o agende diferenciador no mercado de trabalho globalizado. [ 2002?]. Universidade do Estado de Santa Catarina. Disponível em: $<$ http://fido.palermo.edu/servicios dyc/encuentro2007/02 auspicio s_publicaciones/actas_diseno/articulos_pdf/A030.pdf $>$. Acesso em: 24 set. 2011.

[4] Tavares, S. R. S. Modernização industrial em indústria de mão-deobra: automação, informatização e inovações organizacionais na indústria do vestuário. Prod. [on line]. São Paulo, v. 1, n. 1, p. 4148. jan./jun. 1990. ISSN 0103-6513. Disponível em: $<$ http://www.scielo.br/pdf/prod/v1n1/v1n1a03.pdf $>$ Acesso em: 15 maio 2011.

[5] Silveira, Icléia. Usabilidade do vestuário: fatores técnico/funcionais ano 1, n.1, jan./jul. 2008, p. 21-39, Modapalavra e-períodico [on line]. Disponível em:

$<$ http://argeu.ceart.udesc.br/modapalavra/edicao1/artigos/usabilida de iceliasilveira.pdf $>$ Acesso em: 15 maio 2011.

[6] Silveira, Icléia; Silva, Giorgio; Valente, Bianca. A formação e o trabalho dos modelistas nas empresas do vestuário do Estado de Santa Catarina. ano 2, n.4, ago./dez. 2009, p. 4-17, Modapalavra eperíodico [on line]. ISSN 1982-615x. Disponível em: $<$ www.ceart.udesc.br/modapalavra/edicao4/files/1 artigo_silveira silva e valente.pdf $>$ Acesso em: 15 maio 2011.

[7] Batiz, Eduardo Concepción; GALO, Osnildo; SOUZA, Antenor José de. Posturas inadequadas no trabalho: um problema presentes em áreas de tratamento térmico a banho de sal. In: SIMPEP, XIII Bauru, SP, Brasil, 6-8 nov./2006. Disponível em: $<$ www.simpep.feb.unesp.br/anais/anais_13/artigos/422.pdf $>$. Acesso em: 13 mar. 2011.

[8] Freitas, Fabiana Cristina Taubert de; BARBOSA, Letícia Holtz. Análise de riscos biomecânicos presentes na atividade laboral de costureiras industriais. [2005?]. Disponível em:

$<$ http://www2.rc.unesp.br/eventos/educacao fisica/biomecanica2007/u pload $/ 258-1-\mathrm{A}-\mathrm{CBB} \% 20-\% 20 \mathrm{com} \% 20$ autores.pdf>. Acesso em 20 abr. 2011

[9] Lupatini, Márcio. Acumulação de capital e recriação de formas "pretéritas" de exploração: a particularidade da atividade de vestuário. In: Colóquio Internacional Max Engels, V da Unicamp, São Paulo, 2007. Disponível em:

$<$ www.unicamp.br/cemarx/anais_v_coloquio arquivos/arquivos/co municacoes/gt3/sessao1/Marcio_Lupatini.pdf $>$. Acesso em: 25 set. 2011.

[10] Ragasson, C. A. P. Qualidade no trabalho: estudo das condições de trabalho. Paraná: Coluna do Saber, 2004.

[11] Barbosa, Maria do Socorro Alécio; Santos, Regina Maria dos; Trezza, Maria Cristina Soares Figueiredo. A vida do trabalhador antes e após a Lesão por Esforço Repetitivo (LER) e Doença Osteomuscular Relacionada ao Trabalho (DORT). Revista Brasileira de Enfermagem. Brasília 60(5). set-out/2007; p.491-496. Disponível em: <www.scielo.br/pdf/reben/v60n5/v60n5a02.pdf > Acesso em: 10 jun. 2011.

[12] Bernardes, João Marcos; RENNER, Jacinta Sidegum. Fatores de riscos para LER/DORT no setor de montagem de uma indústria de calçados. Fisioterapia Brasil, São Paulo, ano 10, n.13, maio/jun. 2009.

[12] Barbosa, Luís Guilherme. Fisioterapia preventiva nos distúrbios osteomuculares relacionados ao trabalho-DORTs: a fisioterapia do trabalho aplicada. 2. ed. Rio de Janeiro: Guanabara Koogan, 2009.

[14] Gaigher Filho, W.; Melo, S. I. L. LER/DORT: a psicossomatização no processo de surgimento e agravamento. São Paulo: LTr, 2001.

[15] Gontijo, Leila Amaral. Análise ergonômica do trabalho. 2011. 97 slides. Notas de aula.
[16] Guérin, F., Laville, A., DAaniellou, F., Durrafourg, J., Kerguelen, A. Compreender o trabalho para transformá-lo: a prática da ergonomia. São Paulo: Edgar Blücher, 2001.

[17] Iida, I. Ergonomia: projeto e produção. 2. ed. rev. e ampl. São Paulo: Manole, 2005.

[18] MY Mouse Meter.Acompanhe o desempenho do seu mouse e descubra o quanto ele faz por você. Disponívelem: $\Varangle$ http://www.baixaki.com.br/download/my-mouse-meter.htm>. Acesso em: 27 abr. 2011.

[19] Gragnato, Luciana. O desenho no design de moda. 2008. $86 \mathrm{f}$. Dissertação de Mestrado (Mestrado em Design) - Programa de Pós-Graduação Stricto Sensu da Universidade Anhembi Morumbi, São Paulo, 2008.

[20] Brasil, Ministério da Saúde. Doenças relacionadas ao trabalho: manual de procedimentos para os serviços de saúde. Brasília, DF, 2001.

[21] Brasil, Ministério do Trabalho e Emprego. Norma regulamentadora do trabalho $\mathrm{n}^{\circ} 17$ (NR17). 1978. In: Normas regulamentadoras do trabalho. Disponível em: $<$ http://portal.mte.gov.br/legislacao/normas-regulamentadoras1.htm> Acesso em: 29 ago. 2011.

[22] Tablet: que tal desenhar no computador com lápis, pincel ou caneta? Disponível em: $<$ http://todaoferta.uol.com.br/guia/tabletque-tal-desenhar-no-computador-com-lapis-pincel-oucaneta.html\#rmcl>. Aceso em: 25 set. 2011. 